\title{
Blodtrykksapparater på legekontorer
}

\begin{abstract}
Sammendrag
Bakgrunn. Blodtrykksmåling er en av de mest benyttede prosedyrer i klinisk medisin. Vurdering og behandling av blodtrykk genererer store utgifter og har betydelige implikasjoner for de individer det angår. Det er viktig at blodtrykksapparatene gir nøyaktige målinger. Kvikksølvapparater har vært dominerende i hundre år, men erstattes nå av andre typer. Det foreligger ikke nasjonale anbefalinger angående apparatvalg. Målet med denne studien var å kartlegge hvilke blodtrykksapparater som brukes i allmennpraksis og i hvilken grad det var etablert rutiner for kontroll og kalibrering av apparatene.
\end{abstract}

Materiale og metode. I 2007 sendte vi ut et spørreskjema til 65 universitetstilknyttede legesentre i Midt-Norge. Vi spurte om hvilke blodtrykksapparater som var i bruk, og hvorvidt det fantes rutiner for kvalitetssikring av disse.

Resultater. I alt 45 sentre med til sammen 173 leger (tilsvarer $74 \%$ av legene) svarte. Vi registrerte 320 apparater, 18 (6\%) var av kvikksølvtypen. Resten var aneroide eller oscillometriske. Mange sentre hadde 24-timers blodtrykksmålere. To legesentre ( $4 \%$ av legene) rapporterte at de hadde etablert faste rutiner for kalibrering av apparatene.

Fortolkning. Det ser ut til å være behov for å etablere rutiner for kvalitetssikring av blodtrykksapparater i norsk primærhelsetjeneste.

\section{Nils Moe}

nimoe@online.no

Linn Getz

Allmennmedisinsk forskningsenhet

Institutt for samfunnsmedisin

Norges teknisk-naturvitenskapelige universitet (NTNU)

7489 Trondheim

\section{Ketil Dahl}

Carl Johans gate 3

Trondheim

\section{Irene Hetlevik}

Allmennmedisinsk forskningsenhet

Norges teknisk-naturvitenskapelige universitet

Blodtrykksmåling er en av de mest benyttede prosedyrer i klinisk medisin på alle nivåer $\mathrm{i}$ helsetjenesten. Blodtrykk måles dessuten både $\mathrm{i}$ forskningssammenheng $\mathrm{og} \mathrm{av}$ folk i sine egne hjem. Forhøyet blodtrykk, hypertensjon, regnes som en sentral kausal risikofaktor for hjerte- og karsykdom. I kliniske studier er medikamentell blodtrykksbehandling dokumentert som effektivt (1).

Årlig foretas det ca.10,2 millioner kontakter hos allmennpraktikere i Norge, om lag halvparten er konsultasjoner (2). Hypertensjon er hoveddiagnose hos $6 \%$ av pasientene, mens $5 \%$ har diagnosen hjertesykdom (2). Ifølge reseptregisteret ved Nasjonalt folkehelseinstitutt brukte 915380 personer i Norge legemidler for sykdommer i hjerte og kretsløp i 2008. Det tilsvarer et beløp på ca. 2,1 milliarder kroner (3).

Å bli definert som å ha «for høyt blodtrykk» kan påvirke opplevelsen av egen helse i betydelig grad (4). Det er derfor viktig at en slik risikodiagnose ikke stilles uten at det er utvetydig grunnlag for det. Bivirkninger av antihypertensiver og forbruk av helseressurser er andre viktige argumenter for å sikre valid blodtrykksmåling, både i diagnostikk og behandling av høyt blodtrykk.

Leger og medisinstudenter minnes jevnlig på betydningen av riktig måleteknikk, gjentatte blodtrykksmålinger og gjentatte besøk på legekontoret før man tar endelig stilling til om blodtrykket er normalt eller for høyt. Derimot er det, i hvert fall så langt vi har erfart, vanlig å gå ut fra at blodtrykksapparatet i seg selv er i orden og at de målinger som fremkommer er valide. Både internasjonalt (5) og i Norge (6) er det imidlertid vist at det hyppig er feil på blodtrykksapparater som benyttes i klinisk praksis.
De siste 20 årene har økt oppmerksomhet omkring kvikksølvets giftighet ført til at myndighetene nå krever stans $\mathrm{i}$ bruk av kvikksølv i medisinske instrumenter til forskningsmessig og klinisk bruk $(7,8)$. Dette betyr at de klassiske blodtrykksapparatene med visuell skala og kvikksølvkolonne (fig 1) er i ferd med å forsvinne fra klinisk praksis. De erstattes av nyere typer apparater, av henholdsvis den aneroide (fig 2) og den oscillometriske (fig 3) typen (9).

De aneroide topper statistikken over blodtrykksapparater som viser feil verdi (10). Metodikken er å bruke trykkets påvirkning på en liten lufttett (anaeroid) boks. Apparatene er rent mekaniske og beheftet med flere feilkilder. De viktigste feilene skyldes lekkasje av luft og feil nullpunkt på skalaen. Apparatene påvirkes av temperatur og luftfuktighet og kan også endre seg med tiden på grunn av materialslitasje. Man har derfor foreslått at apparater til blodtrykksdiagnostikk og -behandling kalibreres én gang årlig i allmennpraksis og to ganger årlig i sykehus (11).

De automatiske oscillometriske blodtrykksapparatene måler pulsbølgen. Denne omdannes til oscillasjon, og en spesifikk algoritme beregner systolisk og diastolisk trykk av oscillogrammet som fremkommer (12). De automatiske oscillometriske blodtrykksapparatene viser praktisk talt aldri store systematiske feil. Følgende forhold må imidlertid tas hensyn til: Metoden er uegnet ved atypiske pulsbølger. Dette kan føre til feil måling av blodtrykk ved arytmier, spesielt atrieflimmer. Apparatene kan også være upålitelige ved måling på barn, gravide og eldre (13). Automatiske oscillometriske blodtrykksapparater som måler blodtrykket ved håndleddet anbefales ikke ved blodtrykksdiagnostikk og -behandling (14).

Allmennpraktiserende leger er etter vår erfaring ofte i tvil om hvilke apparater de skal velge ved anskaffelse av blodtrykksap-

\section{Hovedbudskap}

- Nye typer blodtrykksapparater har de senere år erstattet kvikksølvapparatene

- Tilfredsstillende rutiner for kalibrering av blodtrykksapparatene ser ut til å mangle i primærhelsetjenesten

- Anbefalinger om hvilket apparat som bør velges ved anskaffelse av ny blodtrykksmåler savnes 


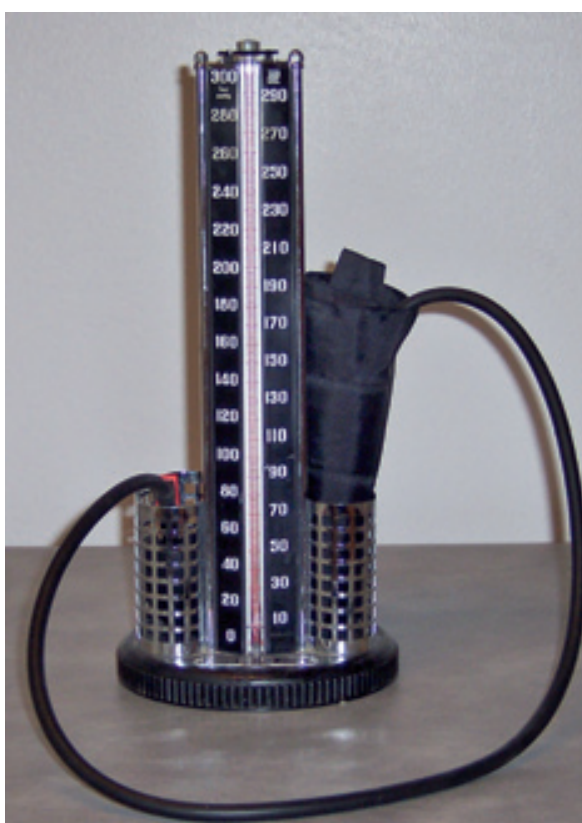

Figur 1 Kvikksølvblodtrykksapparat

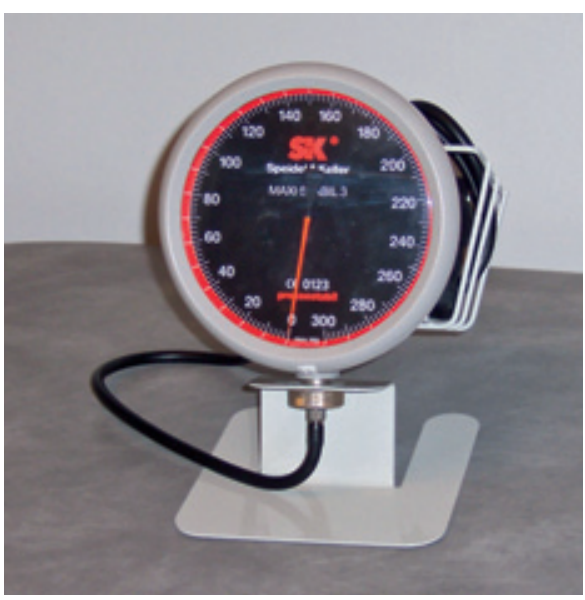

Figur 2 Aneroid blodtrykksapparat

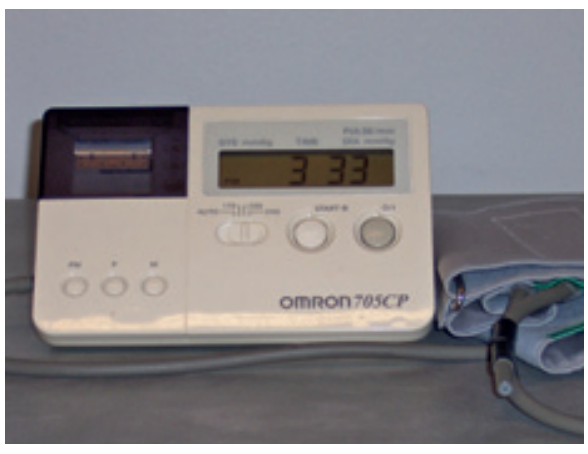

Figur 3 Automatisk oscillometrisk blodtrykksapparat

parater. Det råder også en viss forvirring om validering og kalibrering (ramme 1 (15)). Nasjonale anbefalinger foreligger ikke. I denne studien har vi kartlagt hvilke blodtrykksapparater som er i bruk ved fastlegekontorene i Midt-Norge og i hvilken grad systematiske rutiner for kvalitetssikring av apparatene er etablert.

\section{Materiale og metode}

Vi sendte i januar 2007 et spørreskjema til 65 midtnorske legesentre med til sammen 234 leger. Deltakerne ble bedt om å krysse av for de blodtrykksapparatene som ble anvendt på det legesenteret de arbeidet. Svareren skulle være den adresserte legen ved senteret eller en kollega eller medarbeider ved legekontoret som oppgaven ble spesielt delegert til. Svarkategoriene inkluderte kvikksølvapparater, manuelle aneroide apparater, automatiske oscillometriske apparater og andre. Dessuten ble det spurt om sentrene hadde blodtrykksapparat til utlån og/eller automatisk 24-timers blodtrykksapparat. De ble også bedt om å krysse av for mansjettyper. Til sist ble de spurt om hvorvidt det var etablert rutine for kalibrering av blodtrykksapparatene. Det var også muligheter for frie kommentarer.

Sentrene hadde til felles at minst én av legene hadde formell tilknytning til Institutt for samfunnsmedisin ved Norges teknisknaturvitenskapelige universitet $\mathrm{i}$ Trondheim (NTNU). Tilknytningen var enten som universitetslektor ved lege-pasient-kurs som går over studiets første to år, eller som praksislærer ved utplasseringen av studentene i studiets siste år. Vi purret på svarskjemaer inntil fire ganger på telefon eller telefaks.

\section{Resultater}

Besvart spørreskjema kom fra 45 av 65 mulige legesentre (69\%). Dette omfattet 173 (71\%) av de 243 legene som var målgruppen.

Vi registrerte i alt 320 blodtrykksapparater hos de 173 legene. Totalt var 245 apparater i bruk på legekontorene. I tillegg var det 32 apparater til utlån, og 43 apparater var i bruk for 24-timersregistrering av blodtrykk. Mange leger disponerte flere apparater, mens noen apparater ble brukt av flere leger. Vanlige apparater til utlån og automatiske apparater for 24-timers blodtrykksregistrering var felles for legene på sentrene. I alt 30 legesentre med 96 leger (55\%) delte på 32 apparater til utlån for hjemmemålinger. I alt 144 leger $(83 \%)$ hadde tilgang til et 24 -timers blodtrykksapparat. $7 \%$ av legene hadde verken tilgang til 24-timers blodtrykksregistrering eller tilgang til apparat til hjemlån.

Kun 18 av de 320 blodtrykksapparatene (6\%) var av kvikksølvtypen. Fordelingen av type blodtrykksapparater fremkommer av tabell 1. Legene rapporterte om 43 ulike fabrikater, typer og modeller av blodtrykksapparater. Disse var imidlertid konsentrert om noen store grupper. Welch Allyn (40\% av apparatene), Speidel \& Keller (32\%), Tycos (17\%) og Riester (9\%) dominerte blant produsentene av aneroide blodtrykksapparater. Av 24-timersmålere var det også flest av merket Welch Allyn (60\% av apparatene). Omron hadde produsert $52 \%$ av de automatiske oscillometriske blodtrykksapparatene, mens Welch Allyns apparater utgjorde $21 \%$. Både aneroide og oscillometriske blod-

\section{Ramme 1}

\section{Validering, kalibrering og kontroll} av blodtrykksapparater

- Validering foregår i regi av European Society of Hypertension International Protocol for Validation of Blood Pressure Measuring Devices in Adults.

De siste ti årene har det på nettstedene www.dableducational.com og www.bhsoc.org blitt offentliggjort metoder for validering og lister over anbefalte blodtrykksapparater (15).

- Kalibrering av blodtrykksapparater krever spesiell kompetanse og må gjøres av medisinskteknisk personell med adekvat utstyr.

- Kontroll av blodtrykksapparat kan man på noen basale punkter utføre selv. Viseren skal stå på null når ventilen er helt åpen. Sjekk så ballong, ventil, slange og mansjett. For å undersøke om det er lekkasje i systemet kan man feste mansjetten rundt en massiv sylinder med omkrets på ca. $35 \mathrm{~cm}$. Pump opp til 300 mm Hg, 200 mm Hg, 100 mm Hg og 50 mm Hg og la den stå slik i tre minutter. Man aksepterer maksimalt et fall på 1-2 mm Hg på de tre minuttene. Apne dernest ventilen helt og sjekk at viseren går jevnt og raskt ned og stopper på null. Ved avvik her bør feilen identifiseres og korrigeres, eller det må kjøpes ny slange, ballong eller mansjett. Man kan også kontrollere blodtrykksapparatet mot et annet kalibrert apparat om disse knyttes sammen med en y-kopling, eller mot en gassventil med måler. Feil må uansett korrigeres med spesialverkøy av kvalifisert personell.

trykksapparater ble brukt til hjemmemålinger. Alle de automatiske 24-timersmålerne var oscillometriske.

I tabell 2 beskrives de rapporterte kalibreringsrutinene. Kun to legesentre med til sammen sju leger (4\%) rapporterte faste rutiner for kalibrering av sine blodtrykksapparater. Ett legesenter med tre leger (2\%) anga å ha en løselig avtale med leverandøren av medisinsk utstyr om kalibrering ved behov.

I alt 44 legesentre med til sammen 170 leger ( $98 \%$ av respondentene) rapporterte at de brukte flere mansjettstørrelser.

I spørreskjemaets åpne felt for frie kommentarer etterlyste flere leger veiledning og anbefalinger ved innkjøp av nye blodtrykksapparater.

\section{Diskusjon}

$\mathrm{Ni}$ av ti midtnorske universitetstilknyttede legesentre som deltok i denne studien, rapporterte at de ikke hadde etablert rutiner for 
Tabell 1 Fordeling av blodtrykksapparater ved 45 legesentre i Midt-Norge

Antall Prosent apparater av legene

\begin{tabular}{lrr} 
Manuelle aneroide & 168 & 97 \\
$\begin{array}{lr}\text { Automatiske } \\
\text { oscillometriske }\end{array}$ & 49 & 28 \\
\hline Kvikksølvmanometre & 18 & 10 \\
Sum & 245 &
\end{tabular}

Tabell 2 Rutiner for kalibrering av blodtrykksapparatene Antall Prosent leger av legene

Faste kalibreringsrutiner 7 4

Løselig avtale om muligheter for

kalibrering

Ikke kalibreringsrutiner

Ikke svart

Sum
3 2

89

5

100 kalibrering av blodtrykksapparatene. Siden manuelle aneroide blodtrykksapparater var den største gruppen i bruk på legekontorene, og siden disse apparatene har behov for regelmessig kalibrering, kan det hevdes at blodtrykksmålinger som utføres i diagnostikk og behandling av hypertensjon har et validitetsproblem. Allerede for nesten 30 år siden viste Holmen og medarbeidere i en undersøkelse fra Nord-Trøndelag at det var hyppig feil på blodtrykksapparater i klinisk bruk (6). I internasjonale studier har man funnet det samme (5).

I kommentarene fra legene kommer det frem at de har lite kjennskap til hvordan kalibrering skal gjøres. I noen få av svarene fra legekontorene fremkommer det at leverandører påtar seg å kalibrere apparater som de leverer og at tekniske avdelinger ved noen sykehus tilbyr lokale leger slike tjenester. Kjennskap til validering og anbefalinger av aktuelle blodtrykksapparater på markedet ser i høy grad ut til å mangle blant legene.

Denne undersøkelsen viste at kun $7 \%$ av legene manglet mulighet til å låne ut blodtrykksapparater for hjemmemålinger, enten med vanlig blodtrykksapparat eller med automatisk 24-timersmåler. Dette kan henge sammen med utbredt informasjon om betydningen av blodtrykkets døgnprofil. Dessuten er det velkjent at blodtrykk målt på legekontoret kan ha begrensninger. Spesielt kan det oppstå falskt forhøyet blodtrykk, såkalt kontorblodtrykk (white coat hypertension) (16). Hele $83 \%$ av legene som svarte hadde apparater for automatisk 24-timersmåling. Dette tyder på at ny teknologi raskt har vunnet innpass på dette feltet.

Et adekvat utvalg av mansjettstørrelser ble registrert i studien. Betydningen av mansjettstørrelse virker med andre ord godt kjent.

I henhold til svarerne var det på enkelte apparater vanskelig å definere hva som skulle oppgis som fabrikant, type og modell. Firmaer som produserer blodtrykksapparater har kjøpt opp hverandre, fusjonert, etablert seg på nytt og tidvis blitt lagt ned. I tillegg kommer det stadig nye modeller. Dette kan ha påvirket registreringen, men neppe våre hovedfunn, siden disse kan knyttes til veldefinerte hovedgrupper av blodtrykksapparater.

I denne undersøkelsen registrerte vi ikke hvor stor andel av apparatene i bruk som var validert etter internasjonale prosedyrer.

Legene som deltok i studien var alle allmennpraktikere med en formell avtale om å undervise medisinstudenter. Det er ingen grunn til å tro at de skulle være mindre opptatt av kvalitet $i$ arbeidet enn allmennpraktikere flest. Kvalitetsproblemet knyttet til kalibreringsrutiner for blodtrykksapparater kan derfor antas å være generaliserbart til norsk primærhelsetjeneste.

Norske fastleger har gjennom deltakelse i Norsk kvalitetsforbedring av laboratorievirksomhet utenfor sykehus (NOKLUS) vist at de tar kvalitetssikring av prosedyrer på legekontoret på alvor. Ansvaret for valid blodtrykksmåling i allmennpraksis kan imidlertid ikke utelukkende overlates til fastlegene. I tillegg til at det bør opprettes kalibrerings- systemer som legesentrene kan anvende, er det er behov for klare anbefalinger om å bruke validerte apparater.

Oppgitte interessekonflikter: Ingen

\section{Litteratur}

1. The Task Force for the Management of Arterial Hypertension of the European Society of Hypertension (ESH) and of the European Society of Cardiology (ESC). 2007 Guidelines for the management of arterial hypertension. Eur Heart J 2007; 28: 1462-536.

2. Lunde ES. Hva slags problemer går vi til fastlegen med? Samfunnsspeilet nr. 3/2007. www.ssb.no/ ssp/utg/200703/05 (5.3.2010)

3. Folkehelseinstituttet. Reseptregisteret. 2008. www.reseptregisteret.no (5.3.2010)

4. Sångren H, Reventlow S, Hetlevik I. Role of biographical experience and bodily sensations in patients' adaptation to hypertension. Patient Educ Couns 2009; 74: 236-43.

5. Coleman AJ, Steel SD, Ashworth M et al. Accuracy of the pressure scale of sphygmomanometers in clinical use within primary care. Blood Press Monit 2005: 10: 181-8.

6. Holmen J. Degeneratio sphygmomanometrii - en underdiagnostisert tilstand? Tidsskr Nor Lægeforen 1983; 103: $1530-3$

7. European Commission. Mercury. http://ec.europa.eu/environment/chemicals/ mercury (5.3.2010)

8. United Nations Environment Programme. Global mercury assessment. Genève: UNEP Chemicals, 2002

9. Pickering TG. What will replace the mercury sphygmomanometer? Blood Press Monit 2003; 8: 23-5.

10. Waugh JJ, Gupta M, Rushbrook J et al. Hidden errors of aneroid sphygmomanometers. Blood Press Monit 2002; 7: 309-12.

11. Turner MJ, Speechly C, Bignell N. Sphygmomanometer calibration - why, how and how often? Aust Fam Physician 2007: 36: 834-8.

12. Ramsey M. Non-invasive automatic determination of mean arterial blood pressure. Med Biol Eng Comput 1979; 17: 11-8

13. Nelson D, Kennedy B, Regnerus $C$ et al. Accuracy of automated blood pressure monitors. J Dent Hyg 2008; 82: 35.

14. Palatini P, Longo D, Toffanin G et al. Wrist blood pressure overestimates blood pressure measured at the upper arm. Blood Press Monit 2004; 9 : 77-81.

15. O'Brien E, Atkins N. State-of-the-market from the dableducational.org website. Blood Press Monit 2007; 12: 377-9

16. Angeli F, Verdecchia P. Gattobigio R et al. Whitecoat hypertension in adults. Blood Press Monit 2005; 10: $301-5$.

Manuskriptet ble mottatt 19.6. 2009 og godkjent 8.4. 2010. Medisinsk redaktør Are Brean. 